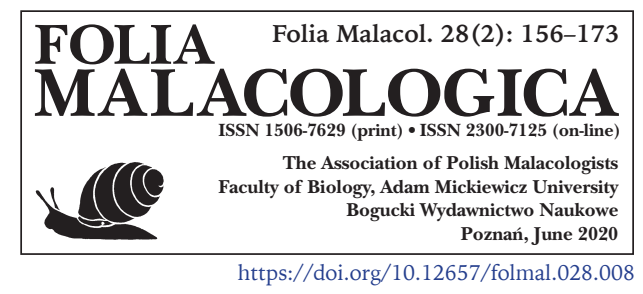

\title{
THE 35TH POLISH MALACOLOGICAL SEMINAR
}

\author{
SEMINAR REPORT
}

The 35th Seminar was held in Szczecin - the third time that a seminar was held in a city (the other two were: Torun Seminar 2018, and the EuroMal in Kraków, 2017), May 15th-17th 2019. Cities are fine, but we are already looking forward to the next one which will be in the Beskidy Mts in Wisła. Nevertheless, we liked it in Szczecin. It is a mediumsized city with lots of possibilities to walk and see historic buildings, and parks; in one we even found a good population of Cepaea. Funnily enough, many participants were convinced that Szczecin was just on the seaside, while the Baltic is actually ca. $100 \mathrm{~km}$ away. Not that anybody grumbled, it was not exactly the right time to swim in the cold sea, not any exotic shells on the beaches, and to fish for amber you'd have to go further east, near Gdańsk.
The Seminar was hosted by the Palaeooceanology Unit, Faculty of Earth Sciences, University of Szczecin; the Chair of Genetics, Faculty of Biology, University of Szczecin; and the Association of Polish Malacologists. The Organising Committee included: GENOWEFA DANISZEWSKA-KOWALCZYK, AGNIESZKA KIERZEK, TERESA RADZIEJEWSKA, MARIANNA SOROKA, BRYGIDA WAWRZYNIAK-WYDROWSKA and ROBERT WOZIŃSKI. Great thanks, we all know how much it takes to organise a seminar!

The Book of Abstracts was edited by JAROSŁAW KOBAK and TOMASZ K. MALTZ, and published by our always-on-duty publisher JAREK BOGUCKI (Bogucki Wydawnictwo Naukowe). Cover design by JAROSŁAW KOBAK, cover photos by BRYGIDA WAWRZYNIAKWYDROWSKA, Seminar logo by MAŁGORZATA BĄK.

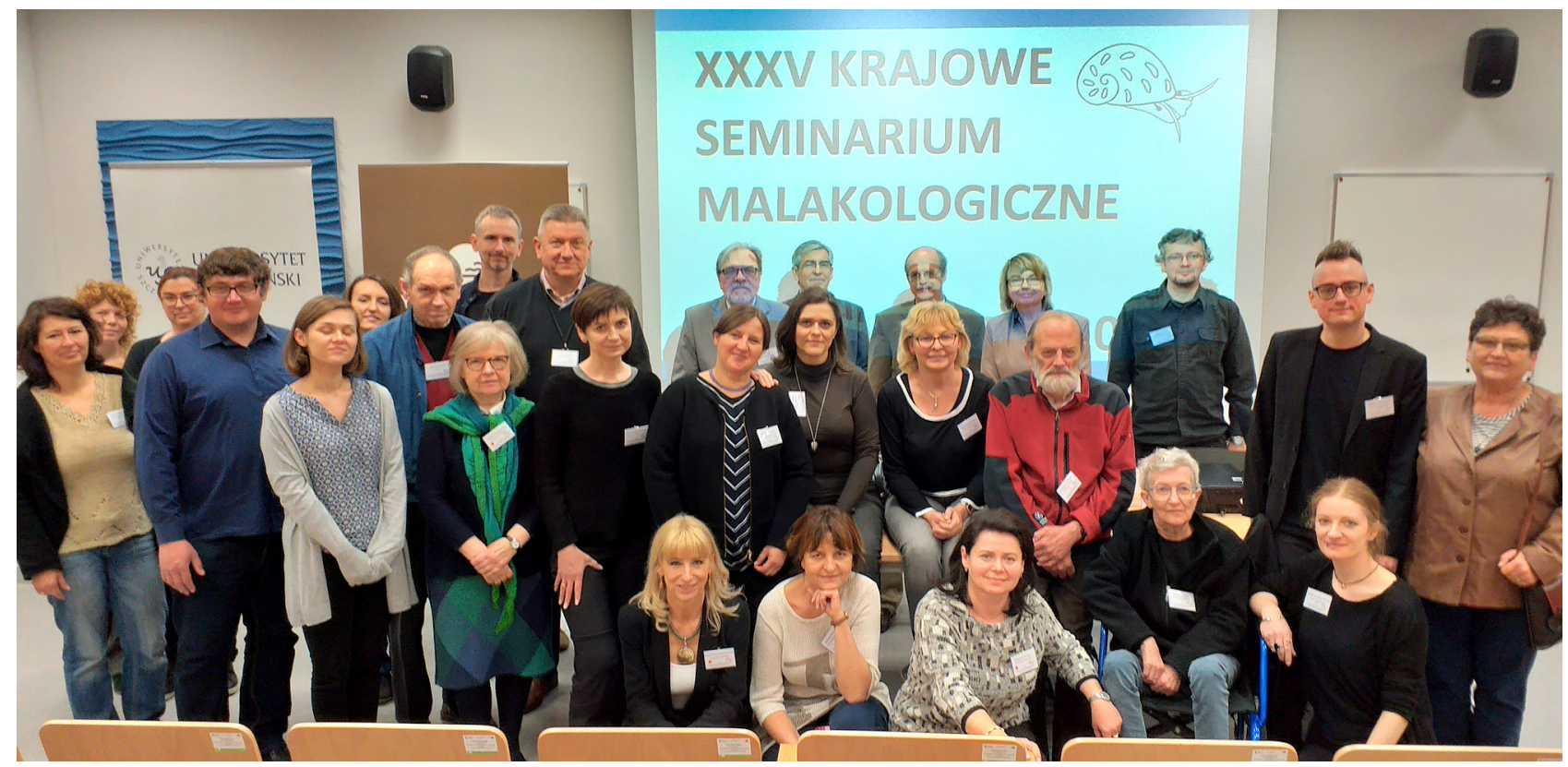

Fig. 1. Participants of the 35th Polish Malacological Seminar. Photo: A. DROzD 


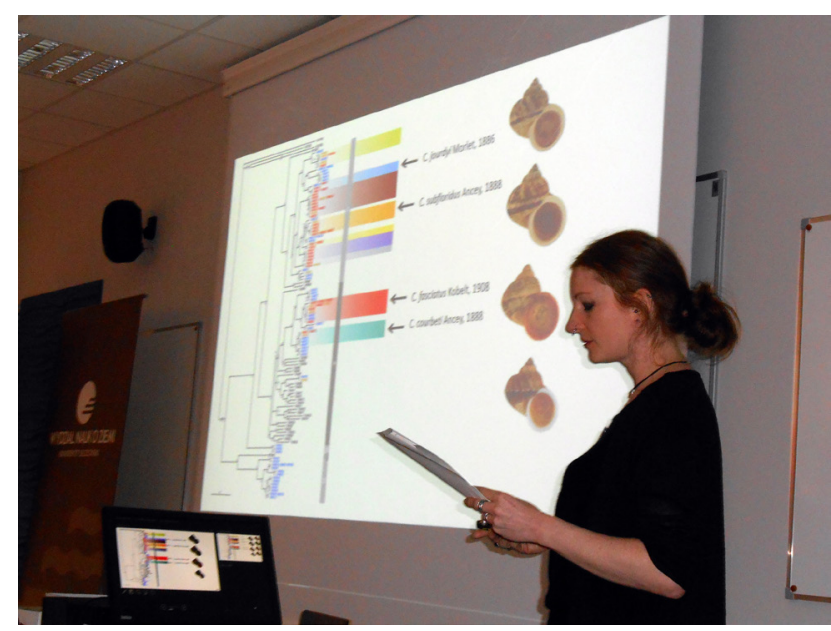

Fig. 2. A lecture about Vietnamese snails. Photo: B. M. POKRYSZKO

The sponsors were: Profoto, Szczecin; Carl Zeiss, Poznań; Macrogen Europe, Amsterdam, the Netherlands and Zespół Parków Krajobrazowych Województwa Zachodniopomorskiego. Great thanks to all of you!

The sessions took place at the University. Regarding accommodation, we were fairly evenly scattered over the city centre and as far as I know nobody complained, especially that nobody was billeted far from the University building. We also had our self-service lunches there (best way to prevent people from being late for the next session). The weather was user-friendly, never preventing us from exploring the city.

The attendance was not very good. There were only 35 malacologists, thus even fewer than the previous year in Torun (45), but very few, if any, failed to appear. Three foreign participants were present: one a faithful member of the Association, and as to the other two we hope they'll fall into a habit of attending our seminars regularly, especially that they brought a new and exotic snaily whiff (Vietnamese limestone-dwelling snails, wow!). Another exotic presentation was by ANNA SULIKOWSKA-DROZD. Though nominally about a method, it dealt with clausiliids from eastern and south-eastern Asia.

The programme contained 20 oral presentations and 9 posters, making a total of 29 contributions (thus the poster:presentation ratio was ca. 1:2, much smaller than during any of our local seminars $(0.9: 1)$, and even more so, compared to the EuroMal (3.7:1). The contributions were distributed among the sessions with only a vague topical division, plus poster session. One presentation was a memorial for the recently departed ANDRZEJ WIKTOR; for obituary see Folia Malacologica 2019. All the presentations were good, but I am always especially glad to see young, beginner malacologists deliver surprisingly good papers, in this case two very good ones by two of our colleagues from Berlin: KATHARINA and PARM VIKTOR VON OHEIMB (obviously yet another malacological couple). Another one I liked very

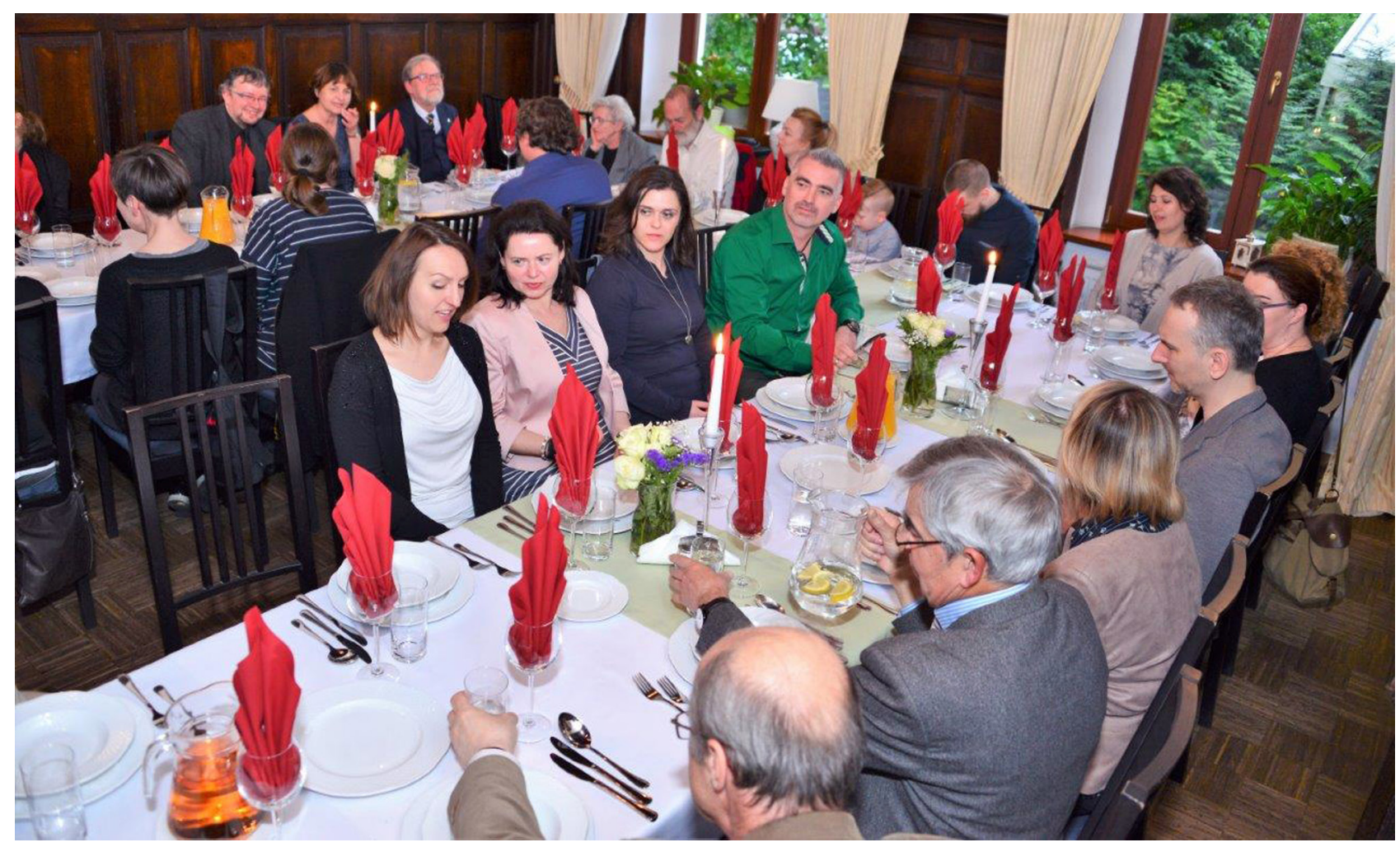

Fig. 3. Banquet. Photo: K. MYZYK 
Table 1. Topical structure of the Polish Malacological Seminars 2007-2018, the EuroMal according to the criteria adopted in the seminar reports, and the 2019 Seminar

\begin{tabular}{clrrr}
\hline No. & \multicolumn{1}{c}{ Discipline } & \multicolumn{1}{c}{$2007-2018$} & \multicolumn{1}{c}{ EuroMal 2017 } & \multicolumn{1}{c}{2019} \\
\hline 1 & Ecology \& Conservation & $196(31.63 \%)$ & $64(25.5 \%)$ & $13(36.11 \%)$ \\
2 & Applied Malacology \& Parasitology & $81(12.66 \%)$ & $17(18.1 \%)$ & $3(8.33 \%)$ \\
3 & Miscellaneous: general, behaviour, archaeology, collections, & $72(11.25 \%)$ & $10(13.0 \%)$ & $3(8.33 \%)$ \\
& history, education, methodology & $48(7.50 \%)$ & $33(45.8 \%)$ & $6(16.67 \%)$ \\
4 & Systematics/Phylogeny (including molecular) & $55(8.60 \%)$ & $18(25.4 \%)$ & $3(8.33 \%)$ \\
5 & Biogeography \& Faunistics & $69(10.78 \%)$ & $6(9.1 \%)$ & $4(11.11 \%)$ \\
6 & Life Histories & $50(7.81 \%)$ & $15(25.0 \%)$ & $2(5.56 \&)$ \\
7 & Fossil Molluscs & $38(5.94 \%)$ & $6(15.4 \%)$ & $1(2.78 \%)$ \\
8 & Structure (histology, cytology, shell) \& Variation & $31(4.84 \%)$ & $4(11.8 \%)$ & $1(2.78 \%)$ \\
9 & Physiology & & &
\end{tabular}

much was by a multi-author team (DAVID ALDRIDGE, ADAM ĆMIEL, ANNA LIPIŃSKA, MANUEL LOPES-LIMA, RONALDO SOUSA, AMILCAR TEIXEIRA, KATARZYNA ZAJĄC, TADEUSZ ZAJĄC) about an unusual behaviour of the thick-shelled mussel (I only wonder what the mussel thought about having so many voyeurs to its sexual behaviour).

The handouts were many, the most appreciated was the thermal mug (ideal for your field coffee) with the Seminar's logo (Theodoxus fluviatilis). The Book of Abstracts had a colony of Dreissena plus some long-tentacled freshwater snails on its cover.

In Table 1 the division into disciplines is the same as that adopted in the previous seminar reports. Columns 3-5 show the numbers and percentages of contributions to the various disciplines from the last Seminar, compared to the general trends at the EuroMal 2017. Considering the small number of presentations during the 2019 Seminar (and thus perhaps not statistically representative), the rough distribution of contributions among the disciplines still differs from that at the EuroMal, and is similar to that during the earlier seminars in that the Ecology \& Conservation are still going strong.

The snail:bivalve ratio was $2.3: 1$ (the mean ratio for the EuroMal 1.3:1), the land:water ratio was 1.6:1 (a novelty: among aquatic presentations the freshwater:marine ratio was 2:1; previously we had hardly any marine contributions). The ratio of one-author contributions to contributions with two or more authors was 1:1 (less than during a few previous Seminars), and the numbers of papers/posters presented by girls versus boys were: girls 12 , boys 6 , mixed teams 11 . The numbers of international contributions vs. all-Polish contributions were 5 and 24, respectively.

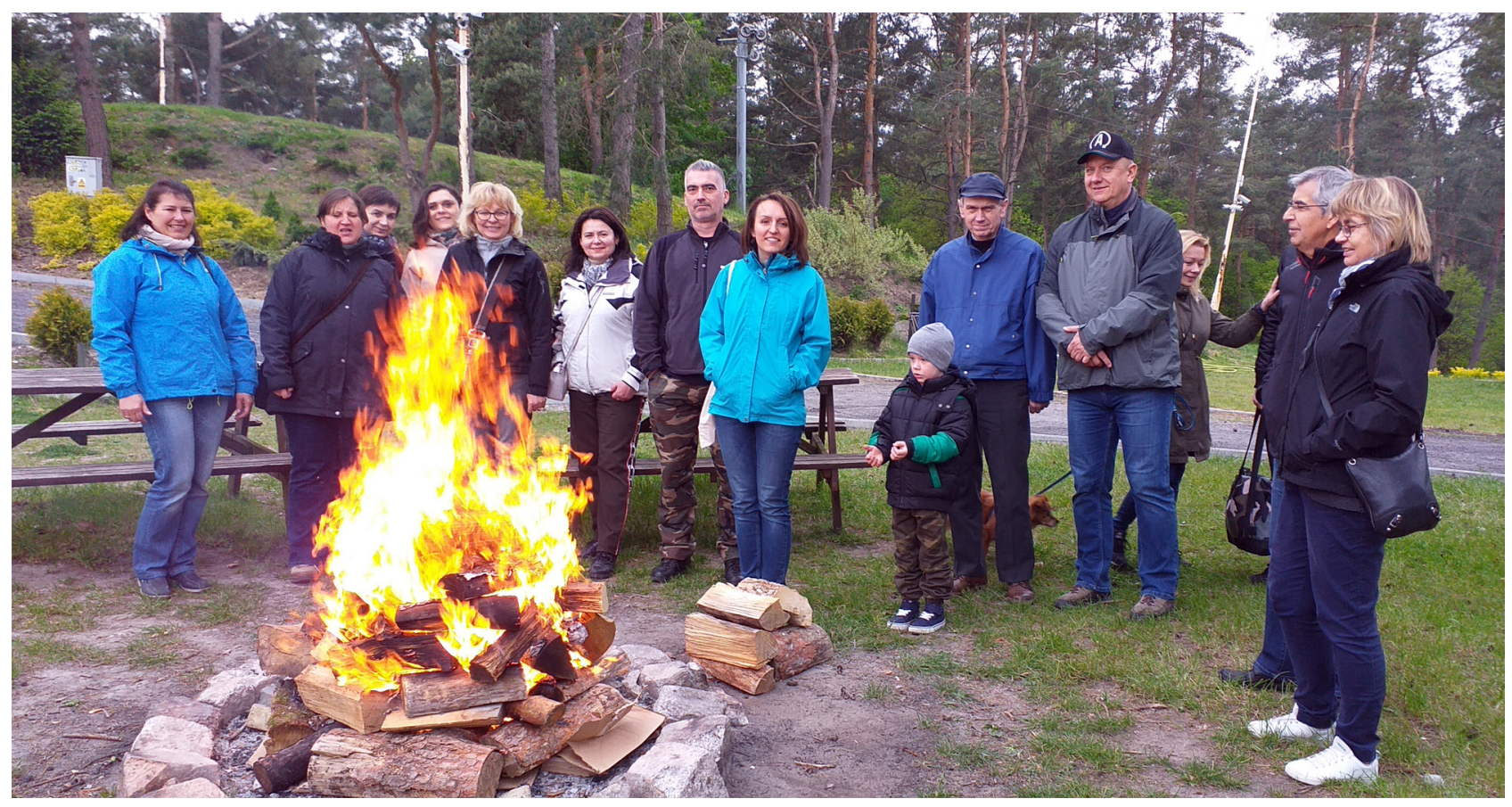

Fig. 4. Seminar bonfire. Photo: A. DROzD 


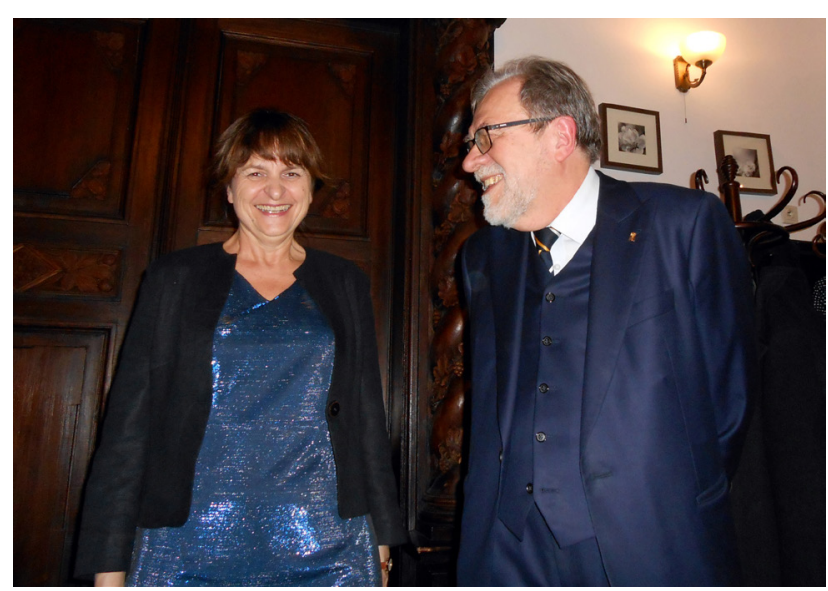

Fig. 5. Two very happy malacologists. Photo: B. M. POKRYSZKO
The attractions included a bonfire with a very good barbecue (superb chicken legs!) on a hill just outside the city, a sightseeing tour around the city and a banquet (during which we acquired one more honorary member).

The abstracts below include all the abstracts from the Abstract Book, most of them translated and some tweaked a bit by the undersigned.

BEATA M. POKRYSZKO

Museum of Natural History, Wrocław University Sienkiewicza 21, 50-335 Wrocław, Poland (e-mail: beata.pokryszko@uwr.edu.pl)

\section{AWARDING HONORARY MEMBERSHIP OF THE ASSOCIATION OF POLISH MALACOLOGISTS (APM) TO PROFESSOR BEATA MARIA POKRYSZKO}

APM's General Assembly convened on September 13th, 2018 during the 34th Polish Malacological Seminar in Torun (see Folia Malacologica 27(2): $127-151,2019)$ unanimously adopted a resolution granting Professor BEATA MARIA POKRYSZKO APM's honorary membership in recognition of her contribution to the development of malacology in Poland and in the world as well as in appreciation for her commitment in APM. The official ceremony was held in Szczecin on May 16th, 2019 during the 35th

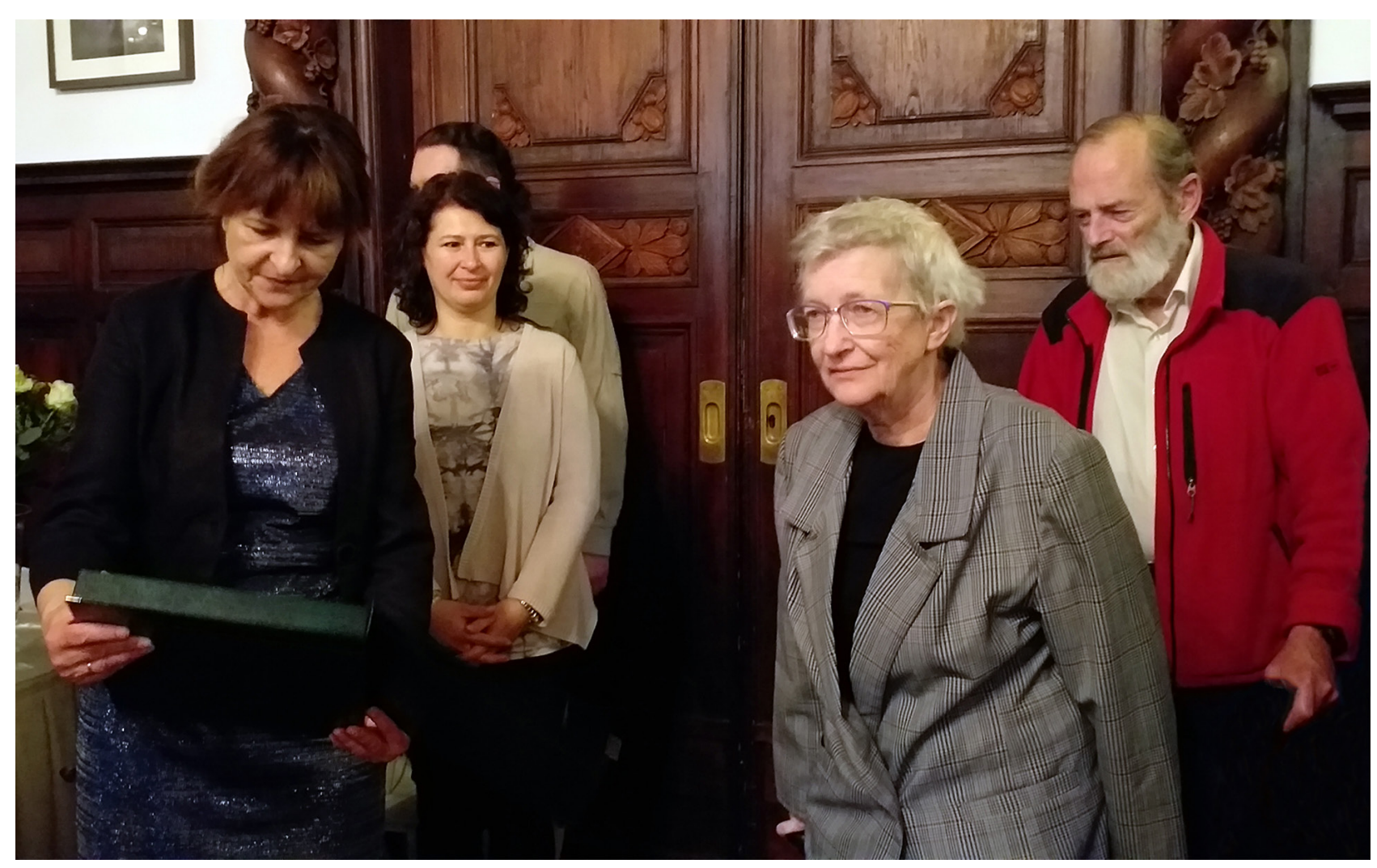

Fig. 6. The president of APM Elżbieta Żbikowska presents the diploma of an honorary member to Prof. Beata Pokryszko 
Polish Malacological Seminar. The official diploma of honorary membership was presented to Professor POKRYSZKO by ELŻBIETA ŻBIKOWSKA, President of the Association of Polish Malacologists at the presence of members attending the Seminar.

The laudation was presented by ANDRZEJ LESICKI who emphasized that "Professor BEATA MARIA POKRYSZKO is a distinguished zoologist and malacologist who has devoted unlimited time to research on this group of animals. He further stressed that her early research focused on the fauna of molluscs in the Kaczawskie Mountains and the Foothills, continued her systematic research on snails of the superfamily Pupilloidea followed by their ecology and life cycles. She then moved to conduct research on biogeography and the evolution of groups of land snails. Professor POKRYSZKO has authored 33 papers published in journals listed in JCR and over $40 \mathrm{pa}-$ pers in other journals as well as chapters of academic textbooks, reviews, popular-research articles, book reviews, communications and other publications."

Professor POKRYSZKO has earned recognition as an esteemed academic teacher of the Faculty of Biological Sciences of the University of Wrocław where she has run courses and delivered monographic lectures, M.A. seminars and conducted specialized workshops. She has trained several dozen B.A. and M.A. graduates and supervised six doctoral dissertations. She has also reviewed several doctoral and post-doctoral dissertations and has been active in her editorial work for a number of scientific journals.

Why Professor POKRYSZKO deserves her APM's honorary membership could be best explained with a long list of merits for the Association of Polish Malacologists. Not only did she attend almost all Polish Malacological Seminars (beginning in Krościenko on Dunajec back in 1985) and frequently presented interesting lectures inaugurating the seminars. Ever since APM's establishment she has played the role of the Association's chronicler recording malacologists' meetings and published her chronicles in Folia Malacologica. Reports from the seminars were supplemented with abstracts of all seminar presentations translated by her into English. Professor POKRYSZKO has co-authored two volumes of "Malakologia Polska - historia, stan obecny, perspektywy" ("Polish malacology - its past, present and future") published in 1999 and 2014 which presented the first 15 years of the Association's activities (from 1985 to 1999) and the second 15 years of APM's activities (from 2000 to 2015). Thanks to her work emotional moments and moving experiences have been recorded and may now be appreciated as a part of APM's history. Professor POKRYSZKO organised and co-organised several seminars, i.e. the 9th Seminar in Mysłów, the 20th Seminar in Krościenko on Dunajec, the 26th Seminar in Kudowa Zdrój and the 30th seminar in Łopuszna. During the 10th Polish Seminar of Polish Malacologists in Obrzycko in 1994 Professor POKRYSZKO was one of the founding members of the Association of Polish Malacologists officially established a year later. She served as APM's Vice-President for two terms of office, i.e. from 1995 to 1999 and from 1999 to 2004. In the subsequent two terms of office (from 2004 to 2008 and from 2008 to 2012) she was a member of the Committee of Awards, whereas in the fifth term of office from 2012 to 2016 she chaired the Audit Committee.

It was thanks to Professor POKRYSZKO's efforts that Folia Malacologica was brought back to its existence in 1998 and since 1999 our journal has been regularly published as a quarterly. Until 2012 BEATA POKRYSZKO was co-editor-in-chief of our journal. She is still endlessly committed doing editorial work and safeguards perfect English of all articles published in the journal.

BEATA POKRYSZKO declares being the self-appointed editor-in-chief of the irregularly published "Ślimakurier" ("The Snail Courier"), originally published from 1996 to 1999 as APM's Newsletter and resumed in 2016, which keeps readers updated and works as a liaison between our annual malacological seminars.

Professor LESICKI concluded his laudation with the following words: "One could also mention all resolutions adopted by the APM thanks to her initiative, including those on the protection of snails but not everything can be measured. What I mean is an immeasurable quality of her character such as openness and readiness to help, both stemming from her personality. To put it in a nutshell, it would be difficult to imagine APM's activities without her contributions. Professor BEATA POKRYSZKO fully deserves the status of an Honorary Member of the Association of Polish Malacologists for her immense knowledge, her world-class scientific accomplishments, popularisation of knowledge about molluscs and remarkable organisational achievements in her work for our Association."

\section{ELŻBIETA ŻBIKOWSKA} President

The Association of Polish Malacologists Faculty of Biological and Veterinary Science Nicolaus Copernicus University, Toruń, Poland (e-mail: ezbikow@biol.uni.torun.pl)

ANDRZEJ LESICKI Folia Malacologica, editor-in-chief Faculty of Biology Adam Mickiewicz University, Poznań, Poland (e-mail: alesicki@amu.edu.pl) 


\section{ABSTRACTS OF THE 35TH POLISH MALACOLOGICAL SEMINAR}

\author{
SPURTING - AN UNUSUAL BEHAVIOUR OF THE \\ THICK-SHELLED MUSSEL (UNIO CRASSUS)
}

DAVID C. ALDRIDGE ${ }^{1}$, ADAM M. ĆMIEL ${ }^{2}$, ANNA M. LIPIŃSKA ${ }^{2}$, MANUEL LOPES-LIMA ${ }^{3}$, RONALDO SOUSA ${ }^{4}$, AMILCAR TEIXEIRA ${ }^{5}$, KATARZYNA ZAJĄC ${ }^{2}$, TADEUSZ ZAJĄC ${ }^{2}$

${ }^{1}$ Department of Zoology, University of Cambridge, Cambridge, UK

${ }^{2}$ Instytut Ochrony Przyrody Polskiej Akademii Nauk, Kraków, Poland

${ }^{3}$ Interdisciplinary Centre of Marine and Environmental Research (CIIMAR/CIMAR), University of Porto, Porto, Portugal

${ }^{4}$ Centre of Molecular and Environmental Biology (CMBA), University of Minho, Braga, Portugal

${ }^{5} \mathrm{CIMO}$ - Mountain Research Centre, School of Agriculture, Polytechnic Institute of Braganca, Braganca, Portugal

Spurting is an unusual behaviour of the thickshelled mussel (Unio crassus), first observed in the early 20th c. The females move to the river bank and spurt streams of glochidia-containing water toward the river bed. No similar behaviour has been observed in any freshwater bivalve species to date. Our aim was to verify the hypothesis that it might serve increasing of the glochidia dispersal and thus the probability of host fish infection. In May 2018 in the Biała Tarnowska River near Lubaszowa we measured the length of the mussels, frequency of spurting, spurting distance, volume of the spurted stream of water, number of glochidia per spurt; we recorded the number and behaviour of fishes near the spurting mussels. Statistical analysis showed a significant correlation between the mussel length, spurt volume and maximum spurting distance. There was no statistically significant dependence between the mussel length and number of glochidia per spurt, or mussel length and spurting frequency. The number of glochidia per spurt grew exponentially with the volume. Ca. $70 \%$ of fishes near the spurting mussels reacted to their behaviour. Spurting may increase the probability of infection of the host fish, albeit its range is limited. Bivalve reproductive behaviour is mostly unknown, but it may prove crucial to explaining the dramatic drop in abundance of endangered freshwater species. In the case of the thick-shelled mussel impossibility to come on shore to spurt may be the reason for its disappearance from regulated rivers.

\author{
ALIEN VS. PREDATOR: DO DIFFERENCES \\ IN ATTACHMENT STRENGTH AND SHELL \\ RESISTANCE EXPLAIN PREDATOR SELECTIVITY \\ BETWEEN DREISSENA POLYMORPHA AND \\ DREISSENA ROSTRIFORMIS BUGENSIS?
}

\author{
CSILLA BALOGH ${ }^{1,2}$, ZOLTÁN SERFŐZŐ ${ }^{1,2}$, \\ JAROSŁAW KOBAK ${ }^{3}$ \\ ${ }^{1}$ Centre for Ecological Research, Balaton \\ Limnological Institute, Hungarian Academy of \\ Sciences, Tihany, Hungary \\ ${ }^{2}$ MTA Centre for Ecological Research, GINOP \\ Sustainable Ecosystems Group, 8237 Tihany, \\ Hungary \\ ${ }^{3}$ Nicolaus Copernicus University, Faculty of Biology \\ and Environmental Protection, Department of \\ Invertebrate Zoology, Toruń, Poland
}

The quagga mussel (D. rostriformis bugensis) has recently joined its long-established congener, the zebra mussel (D. polymorpha) in European waters. This is likely to result in forming new and modifying the existing inter-specific interactions, including direct relationships between the two species, as well as those between them and other organisms, such as inhabitants of mussel beds and molluscivorous predators. We checked how the appearance of the new invader might modify feeding conditions for molluscivorous fishes. We compared the attachment strength (after 2 days, 1 week and 1 month of exposure), shell crushing resistance and glycogen content of dreissenids across their entire size range; we tested whether and how these inter-specific differences translated into the fish predator (common carp, Cyprinus carpio) feeding preferences. The feeding experiment was conducted with unattached live mussels (of various sizes), attached (for 2 days) live mussels and soft mussel tissues freshly removed from the shell. Using this design, we intended to get insight into mussel traits responsible for the possible selectivity of the fish. Small zebra mussels had more resistant shells and stronger attachment than the quagga mussels. These differences were reduced (shell hardness) or reversed (long-term attachment) in larger individuals. Moreover, the zebra mussels had lower glycogen content than the quagga mussels. The fish clearly preferred the quagga over the zebra mussels, irrespective of their attachment status and size. The selectivity also persisted for soft mussel tissues removed from the shell. Thus, the preference of the fish for the quagga mussel depends on selection of higher quality food (higher glycogen content), rather than on the efficiency of the mus- 
sels' anti-predator defence. This also indicates that the fish is capable of recognising this mussel trait, probably using olfactory cues. The quagga mussels appeared to be more susceptible to fish predation than the zebra mussels of the same size. On the other hand, the quagga mussel is also known for its faster growth (probably partly due to partitioning less energy into anti-predation defences), which may protect it from predators that usually either avoid large-bodied mussels or are unable to use them as prey. Financed by the GINOP-2.3.2-15-2016-00019 and MAHOP-2.1.1.-2016-2017-00005.

\section{LAND SNAIL DIVERSITY AND SYSTEMATIC DISCOVERIES: SOME QUESTIONS}

\section{ROBERT A. D. CAMERON}

Department of Animal and Plant Sciences, University of Sheffield, Sheffield, UK

Inventories of land snail faunas from single sites are usually free of systematic problems. Nomenclature may change, but the number of species and their identity is secure. But when comparisons are made, even over short distances, our assessment of similarity may be complicated by the occurrence of different but very similar species: how do we think about this in terms of community structure? The problem is made more acute by the way in which molecular systematics has changed our knowledge of species and species-groups. In some cases, the most clear of which is within the genus Trochulus, a previously recognised group of species is collapsed into one. More often, however, new analyses reveal a set of closely related species where only one was recognised previously. There are many examples. While sets of geographically replacing species within a genus are well-known, this exposes the extent to which our assessment of similarities and differences among faunas are potentially biased by taxonomic decisions. One escape from this is to consider the range of traits in each assemblage. To date, the only traits for which we have comprehensive data relate to shell size and shape. I will present examples that emphasise the apparent functional similarity of different faunas, but also some in which the discordance among faunas raises deep questions about the range of niches occupied by land snails, the significance of genetic differences among species and the role of phylogenetic constraint in the range of morphology that we see.

\section{DO SEASON OF THE YEAR AND THE PRESENCE OF PARASITES AFFECT REACTIONS OF THE ZEBRA MUSSEL?}

\author{
ANNA DZIERŻYŃSKA-BIAEOŃCZYK ${ }^{1}$, \\ ANNA MARIA ŁABĘCKA², ŁUKASZ JERMACZ ${ }^{3}$, \\ ANNA CICHY ${ }^{1}$, JAROSEAW KOBAK ${ }^{1}$ \\ ${ }^{1}$ Zakład Zoologii Bezkręgowców, Wydział Biologii \\ i Ochrony Środowiska, Uniwersytet Mikołaja \\ Kopernika, Toruń, Poland \\ ${ }^{2}$ Instytut Nauk o Środowisku, Wydział Biologii, \\ Uniwersytet Jagielloński, Kraków, Poland \\ ${ }^{3}$ Zakład Hydrobiologii, Wydział Biologii i Ochrony \\ Środowiska, Uniwersytet Mikołaja Kopernika, \\ Toruń, Poland
}

The zebra mussel Dreissena polymorpha has developed an array of defensive reactions in response to environmental pressures. The fastest reaction is closing the valves in order to protect the soft tissues and probably to decrease the risk of detection by the predator. Our earlier research demonstrated valve-closing reactions of $D$. polymorpha to predator smell, alarm substance, or the presence of gammarids in the mussel colony. In further studies the question arose: does the mussel react with similar intensity to the same factors in different seasons of the year and at different stages of gonad development? Considering that some mussels invest up to $90 \%$ of energy in gamete production, we assumed that the same tests conducted in July and November might yield quite different results. In July the mussels, weakened by intensive reproduction, should be less sensitive to stress factors compared to those tested in November, with post-spawning or regenerating gonads. To check the difference in gonad development in both periods, we subjected the gonads to histological analysis, which additionally revealed the presence of echinostomatid metacercariae - another factor which might potentially affect the mussel reaction. We found subtle differences in the reactions. The July females opened their valves more often than those tested in November. The November mussels spent much more time with slightly opened valves. In both July and November the mussels reacted to the presence of gammarids by reducing the time spent with maximally opened valves; the reaction was similar in November in the presence of alarm substance. Irrespective of the experimental variant and season, metacercariae-infected mussels showed a greater frequency of valve movements. The results, though difficult to interpret, suggest that the reactions of D. polymorpha are season-dependent. Further research is needed to estimate the significance of seasonal changes for the reaction to stress factors. Financed by NCN, project 2015/17/N/NZ8/01653. 
COMPLETE SEQUENCING OF THE MITOGENOME OF THE INVASIVE BIVALVE RANGIA CUNEATA SOWERBY

\section{ROMAIN GASTINEAU, BRYGIDA WAWRZYNIAK-WYDROWSKA, ANDRZEJ WITKOWSKI}

Palaeoceanology Unit, Faculty of Geosciences, University of Szczecin, Szczecin, Poland

Rangia cuneata is a bivalve of the order Veneroida. Originally distributed in the Gulf of Mexico, it has now invaded the European brackish waters. A sample of $R$. cuneata was collected in August 2018 from the Świna River (at its mouth to the Baltic Sea). We sequenced its complete mitogenome on a BGISEQ-500 platform. The 60 million paired-end reads were assembled using SPAdes 3.12.0 software. Gene identification was performed with the help of MITOS. The genome is 18,993 base-pairs long. All genes are encoded on the same strand. This mitogenome was used for a multigene phylogeny. By providing complete genome, which includes intergenes and control region, we hope to provide accurate molecular data for the population study of this invasive species.

\section{ESTIMATE OF DISTRIBUTION AND ABUNDANCE OF POPULATIONS OF ROMAN SNAIL (HELIX POMATIA L.) IN LUBUSZ VOIVODESHIP}

\section{JOANNA GOGOL}

Zakład Zoologii Ogólnej i Zbiory Przyrodnicze, Wydział Biologii UAM, Poznań, Poland

The abundance and distribution of Roman snail populations in Lubusz voivodeship were studied from April to September of 2012 and 2016. The location of preferred habitats was preliminarily established using orthophotomaps; the data were then verified in the field. The location of each individual was GPS-determined, the coordinates were entered in the database to visualise the data, ascertain the position of borderline individuals, and calculate the precise area occupied by the populations. The populations were divided into four abundance categories ( $\mathrm{A}$ - very abundant, $\mathrm{B}$ - abundant, $\mathrm{C}$ - sparse, $\mathrm{D}$ - single individuals). The condition of local populations was assessed based on field data: biometric characters (shell diameter and height, weight) and age structure (number of adults and juveniles). The proportion of commercially adult snails (shell $\geq 30 \mathrm{~mm}$ ) was noted for each population to estimate the degree of their exploitation; the number of empty shells was counted to estimate the mor- tality. The total number of snails recorded in 2012 was 5,114 in 193 local populations (2,760 adults, 1,621 juveniles and 733 empty shells); in 2016 the respective numbers were 4,047 snails in 205 populations (2,086 adults, 716 juveniles and 1,245 empty shells). In terms of abundance categories, the number of abundant populations increased markedly (by $16 \%$ ), and the proportion of sites with empty shells only dropped from $8.2 \%$ in 2012 to $2.95 \%$ in 2016 . The proportion of sparse populations remained similar (21.8\% in 2012, $22.2 \%$ in 2016), while the percentage of very abundant populations decreased by $9.8 \%$. The mean adult mass remained constant (23.44 $\mathrm{g}$ in 2012, $23.40 \mathrm{~g}$ in 2016). The proportion of commercial snails was similar: $67 \%$ of the population in 2012 and $68 \%$ in 2016. In the surveyed area the Roman snail is common and the condition of its population is stable.

\section{DYNAMICS, RANGE OF INVASION AND \\ BIOLOGY OF THE AFRICAN SNAIL ACHATINA (LISSACHATINA) FULICA IN ECUADOR}

\section{BARTŁOMIEJ GOŁDYN}

Zakład Zoologii Ogólnej, Wydział Biologii, Uniwersytet im. A. Mickiewicza w Poznaniu, Poznań, Poland

Achatina (Lissachatina) fulica (Férussac, 1821) is among the world's hundred most invasive animal species. Its original distribution range included eastern Africa, from where it spread as a result of accidental or intentional introductions; it is now found in nearly all tropical regions. In South America it was first recorded in the 1980s, and in Ecuador in 2005. Initially only a few sites were known in the western part of the country - in agricultural areas of the Pacific coast. It was thought then that the species would not cross the Andes (in places exceeding 6,000 m a.s.l.) to reach the Amazon forest in the east. However, in 2015 and 2016 we made more than a thousand records of $A$. fulica on the coast and in Amazonia, and even at lower elevations of the Andes where the highest situated sites were above 2,300 $\mathrm{m}$ a.s.l. The only part of Ecuador free of the species seems to be Galapagos, with its very rigorous programme of invasive species control. The species is most often associated with agricultural areas - fruit plantations: bananas, papaya and cocoa. It is also very frequent in urbanised areas where it is of epidemiological importance; it is an intermediate host of Angiostrongylus nematodes which attack mammal respiratory system. More detailed population research in two towns - Puyo (Amazonia) and Babahoyo (coast) and the adjacent banana plantations showed that the population densities were among the great- 
est recorded in literature. Both the population areas and individual ranges were extensive, accompanied by great mobility of the snails (marking-released-recapture) and aggregation behaviour which was not always associated with feeding.

\section{FOOD PREFERENCES OF ARION VULGARIS MOQUIN-TANDON, 1855, AND DEROCERAS RETICULATUM (O. F. MÜLLER, 1774) TO DIFFERENT VARIETIES OF OILSEED RAPE (BRASSICA NAPUS L. SSP. OLEIFERA METZG.)}

\section{MONIKA JASKULSKA ${ }^{1}$, JAN KOZŁOWSKI ${ }^{1}$, MARIA KOZŁOWSKA ${ }^{2}$ \\ ${ }^{1}$ Instytut Ochrony Roślin - Państwowy Instytut Badawczy, Poznań, Poland \\ ${ }^{2}$ Katedra Metod Matematycznych i Statystycznych, Uniwersytet Przyrodniczy w Poznaniu, Poznań, Poland}

Oilseed rape (Brassica napus L. ssp. oleifera Metzg.), (Brassicaceae), and especially its winter form, is a crop most often damaged by slugs (Arionidae, Agriolimacidae). Slug-caused losses are great and sometimes may even reach $70 \%$ of the crop. The plants are most vulnerable to damage at seedling stage and during development of the first proper leaves. The size of slug-caused losses in winter rape crops, as in other crops, depends on the slug population density, food preferences of the pest species and plant vulnerability. Slugs choose plants which are the most palatable to them, which has an influence on their selective feeding; susceptibility of varieties and forms to damage varies. The aim of our study was to determine food preferences of two slug species toward different oilseed rape varieties, to specify the varieties that are more or less susceptible to damage. The tests were done in laboratory, using 11 varieties of winter oilseed rape at the stage of 3-4 leaves, exposed to feeding of Arion vulgaris and Deroceras reticulatum. The results were subject to variance analysis ANOVA and Fisher procedure with significance level $\alpha=0.05$. Plants of the Sherlock variety were damaged to a greater extent by $A$. vulgaris and $D$. reticulatum compared to the Factor variety. Besides, A. vulgaris did more damage to the varieties Kardone and Roberto, and less damage to Gordon. In the case of D. reticulatum, there were no significant differences in the size of damage between the varieties. The information, after testing the results in field conditions, will be used to select varieties for cultivation in slug-threatened areas, as an important component of integrated programme of plant protection against slug pests.

\section{MITOCHONDRIAL GENOME OF MONACHA \\ CARTUSIANA (O. F. MÜLLER, 1774) \\ (EUPULMONATA: HYGROMIIDAE)}

\section{EWA KOSICKA, JOANNA R. PIEŃKOWSKA, ANDRZEJ LESICKI}

Uniwersytet im. Adama Mickiewicza,

Wydział Biologii, Instytut Biologii Eksperymentalnej, Zakład Biologii Komórki, Poznań, Poland

Mitochondrial genes, such as nucleotide sequences coding for fragments of genes of subunit I of cytochrome oxidase (COI) and 16S rRNA are used in evolutionary, phylogenetic and population studies; sequences of mitochondrial genes are used as molecular markers to study taxonomic relationships among gastropod species. Recently, whole mitochondrial genomes have started being used for the purpose. Monacha cartusiana is a terrestrial snail inhabiting nearly the whole of Europe except its north-easternmost fringes. The genus Monacha Fitzinger, 1833 includes ca. 100 species with still partly obscure taxonomic relationships. Our aim was to sequence the mitochondrial genome of $M$. cartusiana, since the full sequence could be used in taxonomic and phylogenetic analyses. We used four pairs of universal primers complementary to conservative sequences of mitochondrial genome. The missing sections between the conservative fragments were identified using primer walking. The resulting complete sequence of mitochondrial genome of $M$. cartusiana includes 13 protein-coding genes (subunits I, II and III of cytochrome oxidase, cytochrome b, subunits 6 and 8 of ATP synthases, subunits $1-6$ and 4 L of NADH dehydrogenase), two ribosomal RNA and 22 sequences coding for transfer RNA. Further research will involve sequencing of mitochondrial genomes of other representatives of Monacha, i.a. M. claustralis, $M$. cantiana, M. atacis and M. cemenelea.

\section{PHASE AND CHEMICAL COMPOSITION OF SHELLS OF HELIX POMATIA AND HELIX LUTESCENS}

\section{MAGDALENA KOWALEWSKA-GROSZKOWSKA ${ }^{1}$, DOMINIKA MIERZWA-SZYMKOWIAK ${ }^{1}$, JOANNA ZDUNEK ${ }^{2}$ \\ ${ }^{1}$ Muzeum i Instytut Zoologii Polskiej Akademii Nauk, Warszawa, Poland \\ ${ }^{2}$ Politechnika Warszawska, Wydział Inżynierii Materiałowej, Warszawa, Poland}

Because of their biocomposite character, shells are of interest to researchers in various disciplines of science. Previous studies focused mainly on shells of aquatic snails. We studied the phase and chemical 
composition as well as the structure of shells of two species of the Helicidae: Helix pomatia and H. lutescens. The techniques used were SEM, EDS and XRD. The two taxa showed a typical structure of interwoven lamellae; phase analyses with Roentgen diffractometer made it possible to ascertain the proportion of amorphous and crystalline phases, as well as the size of crystallites forming the mineral part of the shell. The chemical composition analysis, besides the presence of basic elements of calcium carbonate, revealed trace amounts of other elements.

\section{REMARKS ON THE ASSESSMENT OF ECOSYSTEMS' BIODIVERSITY}

\section{MARIA KOZŁOWSKA}

Uniwersytet Przyrodniczy w Poznaniu, Katedra Metod Matematycznych i Statystycznych, Poznań, Poland

Biodiversity assessment plays a special role in environmental studies, especially monitoring and registering of environmental changes. Indices associated with species diversity and richness, estimating the total number of species, coverage, or abundance, obtained through identification of all the taxa in the ecosystem, characterise it well. Environmental changes documented by a significant increase in values of biodiversity indices are usually interpreted as positive. Despite the difficulties implied in identification of species of small abundance, biodiversity assessment with the indices of Shannon, Simpson, Pielou and others provides the necessary knowledge of richness of every ecosystem. Using the indices to assess species diversity of the ecosystem is very important in considerations on the environment, its protection and ecology.

\section{EFFECT OF TEMPERATURE AND LIGHT ON THE ACTIVITY OF VERTIGO MOULINSIANA (DUPUY, 1949)}

\section{ZOFIA KSIĄŻKIEWICZ-PARULSKA}

Zakład Zoologii Ogólnej, Wydział Biologii UAM, Poznań, Poland

Observations on the effect of temperature and light on the activity of adult and juvenile Vertigo moulinsiana were carried out in laboratory conditions. The activity was observed (1) in the dark, at two temperatures: $6{ }^{\circ} \mathrm{C}$ and $21{ }^{\circ} \mathrm{C}$ during 14 days, and (2) in a $24 \mathrm{hr}$ light-and-dark cycle (12 hrs light/12 hrs dark) at room temperature during 20 days. The snails were kept in vials of $2 \mathrm{ml}$ volume, with high (ca. 99\%) humidity. Juveniles were more active than adults. Both the age classes were more active at $21^{\circ} \mathrm{C}$ than at $6{ }^{\circ} \mathrm{C}$, and more so in the dark than in the light.

\section{SNAILS OF SELECTED HABITATS OF THE DOBRZYŃSKIE LAKELAND}

\section{ELŻBIETA KUŹNIK-KOWALSKA, MARTA FRASUNKIEWICZ}

Zakład Systematyki i Ekologii Bezkręgowców, Instytut Biologii, Uniwersytet Przyrodniczy we Wrocławiu, Wrocław, Poland

The little studied Dobrzyńskie Lakeland (north-central Poland) was surveyed in order to fill the gaps in the gastropod distribution knowledge and to identify symptoms of anthropogenic influence on forest mollusc communities. The number of terrestrial species recorded from the nature reserve Stary Zagaj was 34, with the number of species per site ranging from 8 to 21 , the number of specimens from 38 to 1,224. Most species were euryoecious and/or widely distributed. Compared to other biogeographically and ecologically similar areas of a similar or smaller degree of anthropogenic influence, the human-affected habitats showed unbalanced dominance structure, small between-site similarity and small proportion of forest-dwellers, combined with the near-absence or absence of clausiliids and other tree-climbing and/or timber-dependent species. These seem to be crucial symptoms of anthropogenic changes in effect at present or in the past.

\section{RETROSPECTIVE VIEW OF THE RANGE AND RESULTS OF LONG-TERM STUDIES ON THE LOCAL POPULATION OF ROMAN SNAIL (HELIX POMATIA L.) NEAR THE INSTITUTE OF ANIMAL HUSBANDRY IN BALICE}

\section{MACIEJ LIGASZEWSKI, PRZEMYSŁAW POL Instytut Zootechniki, Zakład Hodowli Drobnego Inwentarza, Balice Poland}

In the 1990s, in an extensive, historic, neglected park surrounding the Radziwiłł palace in Balice near Kraków, and on its fringes, there existed an abundant population of Roman snail. Its splendid condition depended on the habitat conditions which favoured all stages of annual and life cycle of the snail: rather deep calcium-rich soil, herbal vegetation and cultivated plants which were a valuable food source for the snails. The habitat had four components: shaded park with deciduous tree stands, with shrub and herb layer, where the oldest individuals were found; an extensive field, each year sown with winter oilseed rape - an early spring "pasture" for all the age class- 
es; an abandoned meadow with white clover, dandelion and nettle - a feeding ground and development place of young age classes, with ruined greenhouses, where numerous snails hibernated among the brick rubble and mortar crumbs; grassy areas selected by adult snails, and neglected lawns on the park fringes which played the role of breeding grounds. In recent years the park was revitalised which involved cutting shrubs and regular grass mowing in the snails' breeding sites. The ruined greenhouses were demolished, and the meadow was converted into building lots. Of the original habitat components only the oilseed rape (or wheat) field and the surrounding grassland were left. It should be thus assumed that for the above reasons the population is regressing which will be the focus of the planned monitoring studies. To date our studies focused on the age structure, growth rate, reproduction parameters, also their physiological and helicultural aspects, comparison with neighbouring populations; possibilities and effectiveness of active protection; effective reproduction in controlled conditions based on reproducers from the natural population; commercial farming in polyculture with Cornu aspersum; nutritive value and meat yield. We decided that, in view of the above-described radical changes in the habitat of the population, an adequate, retrospective summary was necessary prior to starting new observations on the possible adaptation of the population to the changed conditions.

FIRE - EXTREME HABITAT DISTURBANCE AND ITS EFFECT ON THE POPULATION OF VERTIGO MOULINSIANA

ANNA M. LIPIŃSKA, ADAM ĆMIEL, DOROTA KWAŚNA Instytut Ochrony Przyrody Polskiej Akademii Nauk, Kraków, Poland

Vertigo moulinsiana lives in wetlands where it can be found on green parts of plants and in litter. Its limited capability of active dispersal makes its chances to escape very small. At the same time it is very vulnerable to dampness changes. As a result, it is very susceptible to habitat damage; it can be expected that its ability to react to habitat disturbance should be small. The study plot was located in one of the ca. 40 localities of $V$. moulinsiana in Poland, on the Nida River. Data were collected in 2009-2014, the fire occurred in April of 2012. Population abundance, kind of vegetation, ground relief and depth of standing water were recorded. After the fire the parameters describing the strength of fire and degree of its effect on the habitat were also noted. The fire proved to be disastrous for the population abundance which dropped ca. 25-fold. Neither re-building of the population, nor return to the original abundance were observed. The survivorship distinctly depended on the microhabitat properties. The few survivors were saved thanks to refugia: water-filled ground depressions, covered mainly by Glyceria maxima, which were affected by the fire to a much lesser extent.

\section{GROWTH STRATEGY AND PARENTAL INVESTMENT IN THE ASIAN MUSSEL SINANODONTA WOODIANA (LEA, 1834) (BIVALVIA: UNIONIDAE)}

\section{ANNA MARIA ŁABĘCKA, MARCIN CZARNOŁĘSKI \\ ${ }^{1}$ Uniwersytet Jagielloński, Instytut Nauk o Środowisku, Kraków, Poland}

Human-transformed habitats, including anthropogenic heat islands, constitute favourable places for alien species, even those from remote climate zones. The Chinese mussel Sinanodonta woodiana (Lea, 1834) occurs in cooling waters discharged by the power plant Dolna Odra (West Pomerania). Because of its invasive potential, we started research of its growth strategy and parental investment in the newly colonised area outside the natural range. We confronted the results with the theory of evolution of life strategies. As could be expected, the females showed a greater tendency to indeterminate growth compared to the males; they reached greater asymptotic dimensions and their shells were more convex. Larger females with more convex shells produced larger broods. The proportion of incubating females, brood size and size of glochidia depended on the season and stage of gonad development. Different offspring generations were simultaneously incubated in brood chambers as a result of continuous maturing of oocytes and sequential glochidia release. The phenomenon was not previously known to occur in unionids, and this mode of incubation may be associated with reduced competition of glochidia for host fish and may constitute a form of bet-hedging strategy when attacking a larger number of host-fishes. The brood size in S. woodiana was several times higher than such size in the native European unionids. The mussels most frequently incubated offspring in spring and summer, less often in autumn, while in winter the proportion of incubating females was the smallest. The mean size of glochidia produced in summer was smaller (thermal growth principle) than in winter. Depending on the season, females with mature gonads incubated more numerous large larvae compared to females with post-spawning gonads. The glochidium size was not correlated with the female size, but showed a positive correlation with the brood size for females of the same body size, or negatively correlated with female size for broods of similar size. This suggests that females with ac- 
cess to greater resources produced more numerous and larger offspring. Anthropogenic heat islands form a constant source of Chinese mussel larvae and, as open water bodies, are crucial habitats for the species' spread in Poland. Financed by NCN, project DEC-2017/01/X/NZ8/00946, grant to AMŁ); sponsored by the Institute of Environmental Sciences, Jagiellonian University (DS/WB/INOŚ/757/2018).

\section{RUINS OF ROGOWIEC CASTLE AS A REFUGIUM OF TERRESTRIAL SNAILS IN THE SUCHE MTS (CENTRAL SUDETES)}

TOMASZ MALTZ1, MAŁGORZATA

PROĆKÓW ${ }^{1}$, ELŻBIETA KUŹNIK-KOWALSKA ${ }^{2}$, JAROSŁAW PROĆKÓW

${ }^{1}$ Muzeum Przyrodnicze, Uniwersytet Wrocławski, Wrocław, Poland

${ }^{2}$ Zakład Systematyki i Ekologii Bezkręgowców, Instytut Biologii, Uniwersytet Przyrodniczy we Wrocławiu, Wrocław, Poland

${ }^{3}$ Zakład Biologii Roślin, Instytut Biologii, Uniwersytet Przyrodniczy we Wrocławiu, Wrocław, Poland

The ruins of Rogowiec castle (Central Sudetes, SW. Poland, $870 \mathrm{~m}$ a.s.1., 5041.61' N, 16²18.90'E) situated on a high, rocky hill of Rogowiec, is the highest situated castle in Poland. The hill is built of Permian melaphyres, with steep slopes cut by small, deep valleys. The lower parts are covered by spruce forests or, in places, acid montane beech forest; the immediate vicinity of the castle holds montane-submontane slope sycamore forest (priority habitat of Natura 2000) and rich lowland beech forest. Our objective was to inventory the malacofauna of the castle ruins and slopes in their immediate vicinity, and to compare it with malacocoenoses of the adjacent mountain areas. Forty two species were recorded: 25 in the castle ruins and 39 on the slopes. Forest-dwellers formed the majority (23 species, $71 \%$ ), followed by shade-loving species (7 species). Euryecious (8 species) and open-country (4 species) forms constituted together slightly over $28 \%$ of the malacocoenosis. The malacofauna of Rogowiec was dominated by mesophiles (ca. 81\%). Calciphiles and synanthropic species formed $9.5 \%$ and $7 \%$, respectively. Seven of the recorded species are red-listed in Poland: Orcula doliolum with VU category and six species: Semilimax semilimax, Tandonia rustica, Clausilia parvula, Helicigona lapicida, Causa holosericum and Helix pomatia with NT category. Three of them: T. rustica, H. lapicida and $H$. pomatia, are under partial species protection in Poland. The composition and structure of the malacofauna of the castle hill of Rogowiec do not differ significantly from the malacocoenoses of the neigh- bouring mountain ranges: Kaczawskie, Wałbrzyskie, Sowie and Stolowe Mts (Nei index). The studied area is however much smaller than those mountain ranges, and the castle itself and its immediate vicinity constitute a kind of island surrounded by spruce monoculture. Habitat conditions of the ruins are exceptional, and with its great diversity of microhabitats which increases the species richness the locality plays a part of refugium. The locality should be legally protected as a nature reserve.

\section{SPECIES MANAGEMENT IN AREAS NATURA 2000 - CASE OF VERTIGINIDS FROM OSTOJA SUWALSKA}

\section{MAGDALENA MARZEC}

Suwalski Park Krajobrazowy, Malesowizna 24, 16-404 Jeleniewo, Poland

Natura 2000 areas appeared in Poland when the country joined the EU. These areas are aimed at protecting habitats, or plant and animal species, which are especially important to the Union (listed in Annexes to the Bird Directive and Habitats Directive). The specification of areas Natura 2000 in our country was based on the current knowledge (of varied quality) on the occurrence of habitats and species. An SDF - a standard data form - was prepared for each such area; it contained, among other things, information on all the habitats and species of the area. The habitats and species which meet an array of specific criteria become protected in the area Natura 2000 and protection plans are prepared for them. Regional Directorates of Environment Protection (RDOŚ) are responsible for the management of nature protection in such areas. Because in the Ostoja Suwalska I recorded the occurrence of Vertigo angustior and $V$. moulinsiana, which were not listed in the area's SDF, I sent the pertinent information to the RDOŚ. I was convinced that the institution collected all information about valuable species of the area. It turned out however that RDOŚ was only interested in detailed information which would make it possible to decide if the species met the criteria of protection objects in the area. Appeal to the persons who have detailed (preferably published) data on Natura species which occur in Natura 2000 areas: send the data to the respective RDOŚ (especially when the area's SDF does not contain information on the species you recorded). In Natura 2000 areas the protection focuses on protection objects. The occurrence of species which do not have this status does not guarantee setting limits to the area's management. 
FLOOD EPISODES AND THE CONDITION

OF POPULATION OF CAUCASOTACHEA VINDOBONENSIS IN THE MIDDLE VISTULA VALLEY

\section{DOMINIKA MIERZWA-SZYMKOWIAK}

Muzeum i Instytut Zoologii, Polska Akademia Nauk, Warszawa, Poland

The distribution range of Caucasotachea vindobonensis includes southern and south-eastern Poland; besides, isolated localities are situated in the valleys of Vistula, Warta, Odra and Noteć. In the Middle Vistula Valley the species was recorded from Góra Kalwaria, Otwock and Warsaw. In 2009 C. vindobonensis was found on scarps and floodplains of the Vistula in Skurcza, Wilga, Góra Kalwaria, Ostrówek, Otwock Wielki, Otwock, Górki, Ciszyca and Warsaw. The sites are most often covered by willow and poplar riverine forests, with a shrub and herb layer. Willow forests dominate on young sandy alluvial deposits, poplar forests grow on older and less often flooded deposits. In places the sites hold willow thickets, sand swards and goldenrod thickets. The mean density of C. vindobonensis was 0.25 indiv. $/ \mathrm{m}^{2}$. In 2010 flood waves on the Vistula caused a nearly complete flooding of the sites except Skurcza. One year later live individuals, apart from the site in Skurcza, were found in Wilga, Góra Kalwaria, Ostrówek, Otwock Wielki and Górki. The mean density in those sites was 0.06 indiv. $/ \mathrm{m}^{2}$. In 2015 the species was still present in the sites; besides, it was recorded again in Warsaw. The mean density, including the site in Warsaw, was 0.07 indiv./ $\mathrm{m}^{2}$. Many sites on the Vistula River are temporary. This is mainly caused by flood episodes (which may also cause influx of new individuals), and the time necessary to reconstruct populations from the few survivors or new arrivals.

\section{CRYPTIC DIVERSITY OF CYCLOPHORUS SPP. (CAENOGASTROPODA: CYCLOPHORIDAE) ON VIETNAM'S LIMESTONE KARSTS}

\section{KATHARINA C. M. VON OHEIMB}

Museum für Naturkunde Berlin, Berlin, Germany

The scattered limestone karsts of Vietnam are inhabited by a very diverse land snail fauna, which is still far from being thoroughly explored. Today, many of Vietnam's karst habitats are threatened, particularly due to quarrying for concrete production. Land snails of the genus Cyclophorus, with similar shell morphology, inhabit limestone karsts in various regions of northern Vietnam. Molecular phylogenetic, geometric morphometric and species delimitation analyses showed that these snails belonged to several different species, a number of them previously unknown to science. Populations of different Cyclophorus species with this shell morphology were found to occur strictly allopatrically. Processes, which have shaped the evolution of this cryptic diversity and implications for karst conservation will be discussed.

\section{LAND SNAIL COMMUNITIES (CYCLOPHORUS SPP.) OF LIMESTONE KARST AREAS IN NORTHERN VIETNAM}

\section{PARM VIKTOR VON OHEIMB}

Museum für Naturkunde Berlin, Berlin, Germany

The limestone karsts of northern Vietnam harbour a very rich biodiversity of land snails. Among different karst areas, species communities can differ considerably. The exact processes that have shaped the composition of individual karst communities, however, remain largely unknown. In the present study, the impact of two assembly processes: inter-specific competition and filtering of taxa due to geographical factors, was investigated for communities of Cyclophorus spp. (Caenogastropoda: Cyclophoridae). Phylogenetic relatedness and similarity of shell morphology were used as proxies for ecological similarity and analysed to reveal patterns of overdispersion (indicating competition) or clustering (indicating filtering) in the observed communities compared to random communities. The analyses revealed patterns of phylogenetic and morphological overdispersion for a majority of the studied karst areas. These findings highlight the importance of inter-specific competition for shaping of the Cyclophorus communities in northern Vietnam.

\section{NEW LOCALITIES OF MONACHA CANTIANA (MONTAGU, 1803) AND M. ATACIS GITTENBERGER ET DE WINTER, 1985 (EUPULMONATA: HYGROMIIDAE) IN FRANCE}

JOANNA PIEŃKOWSKA ${ }^{1}$, MAŁGORZATA PROĆKÓW ${ }^{2}$, EWA KOSICKA ${ }^{1}$, FOLCO GIUSTI ${ }^{3}$, GIUSEPPE MANGANELLI ${ }^{3}$, DEBORA BARBATO ${ }^{3}$, ANDRZEJ LESICKI ${ }^{1}$

${ }^{1}$ Zakład Biologii Komórki, Uniwersytet im. Adama Mickiewicza, Poznań, Poland

${ }^{2}$ Muzeum Przyrodnicze, Uniwersytet Wrocławski, Wrocław, Poland

${ }^{3}$ Dipartimento di Scienze Fisiche, della Terra e dell'Ambiente, Universitá di Siena, Siena, Italy

The present results are a continuation of research on the phylogenetic relationships and distributions of 
snails of the genus Monacha Fitzinger, 1833 in Europe, based on integrative analysis of morphological (shell and reproductive tract) and molecular (sequences of selected mitochondrial and nuclear gene fragments) features. The vast majority of about 100 species described in this genus occur in relatively small areas, mainly the southern Balkans, Anatolia and the Pontic-Caspian region. The few exceptions include Monacha cartusiana (O. F. Müller, 1774), a species occurring in almost all of Europe, with the exception of the north-eastern fringes (Scandinavia, Russia, Baltic republics, Belarus). Its occurrence in France, known for a long time, was confirmed in the Department of Aude by our molecular analysis. Another of the few exceptions is $M$. claustralis (Rossmässler, 1834), originally found in European and Anatolian Turkey and in Greece, and currently found by us in many localities in central Europe. Recently, we found it also in Romania and Moldova and it was reported from eastern Germany in the 2019 publication. Monacha cantiana (Montagu, 1803) was described from Kent in Great Britain. We showed a close affinity between the English populations and those from the Latium region around Rome and at the same time a wide diversity of other populations occurring in Italy. On one hand, this suggests that the species originated in Italy, where it still differentiated, and on the other hand that it might have been introduced into Great Britain in modern times. This hypothesis is confirmed by our discovery of ten localities of $M$. cantiana s. str. in Normandy. Individuals of these populations are characterised by haplotypes of mitochondrial genes typical of English populations, and of populations from the region of Latium. Monacha atacis Gittenberger et de Winter, 1985 is a species described relatively recently from southern France at the foot of the Pyrenees. Our molecular analysis confirmed that specimens from the 15 populations of the Aude and Ariège departments, i.e. the regions close to the locus typicus of $M$. atacis, belong to this species. Preliminary results indicate a close affinity (or even identity) between the populations of $M$. atacis and $M$. samsunensis (Pfeiffer, 1868), a species occurring on the coasts of the Black Sea, from northern and central Anatolia to Batumi (Georgia) and Novorossiysk (Russia). This may be another case of introduction of a species, native to the southern Balkans and Asia Minor, into Western Europe, like the case of the population of M. ocellata (Roth, 1839) discovered last year in Great Britain.

\section{ANDRZEJ WIKTOR (1931-2018). MEMORIAL}

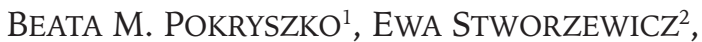 ANDRZEJ LESICKI ${ }^{3}$}

${ }^{1}$ Muzeum Przyrodnicze Uniwersytetu

Wrocławskiego, Wrocław, Poland

${ }^{2}$ Instytut Systematyki i Ewolucji Zwierząt, PAN, Kraków, Poland

${ }^{3}$ Zakład Biologii Komórki, Uniwersytet im. Adama Mickiewicza, Poznań, Poland

Professor Andrzej Hubert Wiktor passed away on December 31st 2018, and was buried on January 8th 2019 in the Holy Family Cemetery in Wrocław. Andrzej Wiktor was born on the 4th of February 1931 in Nowa Wieś on the Wisłok River, near Rzeszów, as a son of Józef Wiktor and Maria Wiktor neé Łoś. He went to school in Czudec, Gorlice and Sopot. Having passed his school-leaving exams in 1949, he started his biological studies at Poznań University and then continued the University of Wrocław, to pass his master's exams in 1954. In the same year he married Jadwiga Kwiecińska; their daughter Zofia was born in 1955. Jadwiga died in 1997. In 2002 Wiktor married Hanna Mizgajska. Andrzej Wiktor's first employment was a half-time job at the Medical University in Wrocław. Till 1958 his consecutive positions were assistant, senior assistant and adjunct [associate professor]. Having obtained his doctoral degree in 1962, Wiktor moved to the Natural History Museum, Wrocław University, where he worked full time till 2002. He habilitated in 1971, became professor in 1980 and ordinary professor in 1989. In 1963-2002 A. Wiktor held various posts not only at the Museum but also at the University (for details see Folia Malacologica 19: 193-200: Appendix I). In 1984 he was elected Rector Magnificus, but for political reasons the then Minister of Science and Higher Education refused to endorse the election. He was supervisor of three and referee of 14 doctoral theses, seven habilitation dissertations and 15 applications for professorship. He remained active for a long time after his retirement; mainly continuing his malacological work as a volunteer at the Museum, and was active in the prestigious Polish Academy of Arts and Sciences. Andrzej Wiktor was active in a variety of institutions and organisations outside the University, as well as in editorial boards and committees; his achievements in many various fields earned him an array of awards and distinctions. The total number of his publications is 107, most of them (78) mainly or exclusively about slugs; they include 11 books or book chapters. Most of them are richly illustrated by the Author who was a very good artist. Andrzej Wiktor collaborated with many malacologists within the country and abroad. Wiktor's slug papers deal with systematics, morphology, ecology, biogeography 
and phylogeny. His main scientific achievements include proposing a new, original system of slug classification, studying and applying the structure of pallial complex in phylogenetic studies, documenting parallel evolution in slugs, demonstrating the role of spermatophores as hybridisation barrier in the Milacidae, monographs of Milacidae, Parmacellidae, Anadenidae, Agriolimacidae, as well as the first monographs of the slugs of Poland, Bulgaria, ex-Yugoslavia, Greece, Pakistan, China, ex-USSR and its adjacent countries, description of numerous new taxa, synonymisation of several dozen names, and the analysis of endemism of the Balkan slugs. Other malacologists, especially beginners dealing with the terrestrial malacofauna of Central Europe, highly appreciate Wiktor's guide to terrestrial gastropods of Poland. Till now, during more than 50 years, he managed to accumulate the world's most abundant and species-rich collection of slugs, now at the Natural History Museum in Wrocław. He mainly collected them himself during his field trips in Poland, as well as in Croatia, Turkey, Bulgaria, ex-Yugoslavia, Greece, Spain, Italy, Tadzhikistan, Papua-New Guinea and China. Professor Wiktor became honorary member of our Association in 1997 at the 14th Polish Malacological Seminar. He was a very friendly and open person, always ready to extend his helping hand to those who needed it. He was not only an outstanding and well-known scientist (those are many), but also very much liked as a person, as shown by the vast numbers of mourners at his funeral. We will miss him a lot.

GENETIC AND MORPHOLOGICAL ANALYSIS OF XEROCAMPYLAEA WALDEMARI, A FORGOTTEN SPECIES FROM THE BALKANS (GASTROPODA: HYGROMIIDAE: URTICICOLINI)

MAŁgorzata ProćKóW ${ }^{1}$, Michael DUdA², LUISE KRUCKENHAUSER ${ }^{3}$, WIM J. M. MAASSEN ${ }^{4}$, ANTON J. DE WINTER ${ }^{4}$, PAWE€ MACKIEWICZ ${ }^{5}$

${ }^{1}$ Muzeum Przyrodnicze, Uniwersytet Wrocławski, Wrocław, Poland

23rd Zoological Department, Museum of Natural History Vienna, Vienna, Austria

${ }^{3}$ Central Research Laboratories, Museum of Natural History Vienna, Vienna, Austria

${ }^{4}$ Naturalis Biodiversity Center, Leiden, the Netherlands

${ }^{5}$ Zakład Bioinformatyki i Genomiki, Wydział Biotechnologii, Uniwersytet Wrocławski, Wrocław, Poland

Proper species identification has an effect on the knowledge of biodiversity: precise identification is necessary to plan and execute effective conservation studies, especially in biodiversity hotspots and
Pleistocene refugia. The Balkans are among such regions, and their malacofauna is still poorly known. Based on the material collected in the field and museum specimens we assessed the taxonomic status of the endemic Balkan Fruticicola waldemari Wagner, 1912. The species was earlier included in Trochulus. Molecular and morphological analyses showed its close relationships with the Urticicolini, especially Xerocampylaea erjaveci. Anatomical and morphological data (folds on penis transverse section, shell miscrosculpture, umbilicus diameter and sequences of mitochondrial markers COI and 16S rRNA) demonstrated that $X$. waldemari and $X$. erjaveci were distinct species, both members of the genus Xerocampylaea. Specimens collected in the terra typica served as the basis for redescription of $X$. waldemari. The results will provide a starting point for taxonomic studies on the different populations of the species, and for detailed analyses of the very variable related $X$. erjaveci. Financed by SYNTHESYS (project NL-TAF-4425) and NCN (project 2016/21/B/NZ8/03022).

\section{ABYSSAL MALACOLOGY}

TERESA RADZIEJEWSKA, BRYGIDA WAWRZYNIAK-WYDROWSKA

Zakład Paleooceanologii, Wydział Nauk o Ziemi, Uniwersytet Szczeciński, Szczecin, Poland

The presence of bivalves and snails in abyssal depths $(>4,000 \mathrm{~m})$ has been known since the pioneer expedition of HMS "Challenger" (1872-1876). The knowledge of these organisms was supplemented by subsequent expeditions which provided most of all qualitative data and discoveries of new taxa, including some living fossils (e.g. Neopilina galatheae). Quantitative data are much poorer, but it is known that bivalves and snails, next to polychaets and Peracarida crustaceans, are the third most numerous group of benthos of deep ocean bottom. Nevertheless, the abyssal malacofauna remains very little known, and the distribution of the data on its abundance, biomass and diversity is geographically very uneven. One of the least known areas in this respect is the Clarion-Clipperton Fracture Zone, CCFZ, in the Pacific; there exist exploitation plans regarding its resources (polymetalic concretions). The paper presents the sparse data on the malacofauna of the CCFZ; based on materials from the cruise SO239 of the ship "Sonne" (March-April 2015) within the JPIO programme "Ecological Aspects of Deep Sea Mining" examples are given of taxa which occur in the concretion-bearing areas of this zone, with emphasis on the significance of better knowledge of biodiversity of the area under severe anthropogenic threat. Financed by NCN, project 2014/13/B/ST10/02996 
STATE OF KNOWLEDGE OF DOUBLY

UNIPARENTAL INHERITANCE OF MITOCHONDRIAL GENOME IN EUROPEAN UNIONIDS

\section{MARIANNA SOROKA}

Uniwersytet Szczeciński, Wydział Biologii, Katedra Genetyki Ogólnej i Molekularnej, Szczecin, Poland

Freshwater bivalves of the family Unionidae display an inheritance system of mitochondrial genome which is unique in the animal world: doubly uniparental inheritance (DUI). It was first described in the genus Mytilus in 1990, and is at present known to occur in ten phylogenetically remote bivalve families (Mytilidae, Unionidae, Margaritiferidae, Hyriidae, Veneridae, Donacidae, Nuculanidae, Mactridae, Arcticidae and Solenidae). Two types of mitochondrial DNA are observed in DUI: haplotype F (type F or female genome), inherited from the mother, and haplotype $\mathrm{M}$ (type $\mathrm{M}$ or male genome), inherited from the father. Females are homoplasmatic and have only one mtDNA of $\mathrm{F}$ type, which they inherited from the mother to transmit it further to next generations via their female offspring. Males are heteroplasmatic and have both forms of mtDNA. The male $M$ type mitochondrial genome, located in the gonads, is obtained from the father and transferred further to the male offspring. Male somatic tissues contain F type mtDNA, which the male inherited from the mother and does not transfer it to next generations. Both mitochondrial genomes in bivalves are of similar size (ca. 16,000 bp), they contain 37 typical genes and are much varied genetically. $M$ type is usually longer and evolves faster than F type. Among the Unionidae which include more than 670 species, till now DUI has been described in more than 60 species, five of them occurring in Europe.

\section{USING MUSEUM SPECIMENS TO STUDY SNAIL REPRODUCTIVE STRATEGIES}

\section{ANNA SULIKOWSKA-DROZD}

Katedra Zoologii Bezkręgowców i Hydrobiologii, Uniwersytet Łódzki, Łódź, Poland

Malacological collections, accumulated for nearly 150 years, are usually regarded as a basis for taxonomic and biodiversity studies, but they may as well provide data on some characters of life strategies of viviparous snails. This is possible due to computer microtomography based on Roentgen radiation. It makes it possible to detect structures of different density in the animal's body. Among other advantages is the possibility to visualise embryonic shells and egg shells in preserved material, when the offspring develops within the snail's reproductive system. The effectiveness of the method, quite safe for the museum material, is confirmed by studies on clausiliids. The material came from unique collections which included rare and nearly-extinct species from hardly accessible regions of the world (mainly eastern and south-eastern Asia). The research was done on 140 species of the Phaedusinae, i.e. ca. $30 \%$ of species described within the subfamily. The total number of analysed specimens was ca. 1,000 (collections of Museum National d'Histoire Naturelle, Paris; Naturalis Biodiversity Center, Leiden; Malacology collection; Museum of Comparative Zoology, Harvard University; Natural History Museum, London; MiIZ PAN, Warsaw; as well as collections of E. Stworzewicz, M. Szekeres and W. Maassen). Most were dry shells (86\%), the remaining specimens were alcohol-preserved. The total of 205 specimens (19\%) contained eggs or embryos. In wet samples ca. $26 \%$ of specimens were gravid; embryos were also found in $18 \%$ of dry shells. Embryos were present in species of the genera Phaedusa, Euphaedusa, Paraphaedusa, Reinia, Parazaptyx and Metazaptyx. The number of offspring was 1-12 per specimen (usually $1-5)$. Most of the embryonic shells ranged from 1.5 to 3 whorls. Besides, in some species, i.a. Oospira javana, O. miranda, Hemiphaedusa ooi, calcified egg shells and small embryonic shells ( $<1$ whorl) were observed. The observations indicate a short embryo-retention. In species in which embryos were detected at least once (533 specimens of 45 species) the proportion of gravid specimens was $38.5 \%$. The studies contributed to the knowledge of the commonality of parental care-associated strategies (viviparity, embryo-retention) in the Clausiliidae. Financed by NCN, project 2016/21/B/NZ8/03086.

\section{MYSTERIOUS PATHOLOGIES IN MYA ARENARIA AND OTHER DEEP-BURROWING BIVALVES}

\section{PRZEMYSEAW SZTAJNER}

Laboratorium Paleobiologii, Wydział Nauk o Ziemi, Uniwersytet Szczeciński, Szczecin, Poland

Among the shells of Mya arenaria washed on to the shore of the Bay of Pomerania by the Baltic waves many are atypically formed. Apart from slight deformations of outline, only slightly departing from the usual intra-specific variation, most are pocket-like structures on the inner side of the valve; they occupy the whole or a part of siphonal sinus and are open backward. In specimens which continued growing after formation of this structure, it opens to the outside of the shell since the growth continued starting with the pocket edge and not on the earlier valve edge. I found similar structures before in many species of 
Jurassic Anomalodesmata from the Kraków-Wielun region. They occur most often in Pholadomya spp. In the fossil specimens they are even more varied (located on different parts of the shell, even inside the pallial line), but most often located as in $M$. arenar$i a$, in the siphonal sinus, but contrary to $M$. arenaria they always take the whole sinus area. Among the bivalve pathologies described to date, the most similar are Polydora-caused mud blisters in oysters. In the cases I studied the pathogene must have been different, since all those species are deep-burrowing, and though the polychaete lives under the bivalve's mantle, it filters food from the water. The blisters arise through damage to free periostracum, causing penetration of the sediment into the extra-pallial space and inducing the animal to form a new shell wall inside the old one, at the mantle surface. Polydora deepens the so formed pocket, but my specimens show no traces of such activity. The reason must thus be different - the most likely is infection with metacercarie of flukes resembling the Gymnophallidae, whose numerous species occupy analogous positions in many recent bivalves. The discovery of the same pathology in a representative of extant fauna makes it possible to verify this hypothesis, but it requires histopathological examination of live specimens.

\section{SUBFOSSIL MOLLUSC ASSEMBLAGES OF THE ŚWINA GATE}

\section{ROBERT WOZIŃSKI}

Muzeum Geologiczne, Uniwersytet Szczeciński, Szczecin, Poland

The aim of the research was to recognise the stratigraphic diversity of litho- and biofacies accumulated in the region of the Świna Gate, using mollusc assemblages, in different sedimentation environments during the Holocene. The total number of subfossil specimens obtained from 2,363 deposit samples was 232,304 representing 41 species, classified into six ecological groups. Shells of brackish species were the most numerous $(66.4 \%)$, followed by marine $(33.1 \%)$, freshwater and terrestrial $(0.5 \%)$ forms. Based on the geological, granulometric and malacofaunistic analyses, as well as radiocarbon dating of organic sediments and shells of Cerastoderma (Cardium) glaucum, the following series of deposits were distinguished: glacifluvial series, fluvial series, fluvial-paludal series, marine series, dune-beach series, delta series, lagoon series and alluvial plain series. Twenty assemblages (biofacies) named for taxa with the highest dominance and constancy were distinguished in the analysed profiles. The mollusc assemblages were included in four facies (biofacies): marine, brackish-marine, brackish and freshwater.
Shells of C. glaucum embedded in the deposits in an in vivo position, and biogenic deposits underlying marine deposits made it possible to specify the time boundaries of transgression of the Littorina sea. The transgression onto the present Świna Gate and the Gulf of Szczecin took place from ca. 7,700 to 7,000 calibrated years BP. A consequence of the transgression/ingression was formation of an open lagoon Szczecin Lagoon. The lagoon was short-lasting, since it was rather quickly closed by the growing Uznam Bar (Karsibór Bar) and Wolin Bar (Przytór Bar). Based on the age of shells of C. glaucum, found in an in vivo position, the time of sedimentation of marine deposits in the Świna Gate lasted ca. 3,780 years $(6,819$ to 3,043 calibrated years BP). The proportion of marine fauna in the assemblages of known radiocarbon age showed that for ca. 5,800 calibrated years BP the bottom parts of the profiles were dominated by typically marine fauna (assemblages with C. glaucum). Since ca. 5,500 calibrated years BP there was a distinct change in the malacofauna associated with a decrease in salinity. The tendency became more intensive since ca. 4,000 calibrated years BP, leading to succession of brackish assemblages.

HOST ROLE OF POTAMOPYRGUS ANTIPODARUM (J. E. GRAY, 1853)

\section{ELŻBIETA ŻBIKOWSKA}

Zakład Zoologii Bezkręgowców, Wydział Biologii i Ochrony Środowiska, Uniwersytet Mikołaja Kopernika, Toruń, Poland

Potamopyrgus antipodarum, often regarded as an invader from New Zealand, has for a long time been spreading outside its natural range. It is now widespread in the north-east Atlantic region, Baltic Sea, canals and inland waters of Asia, North America, Europe and Oceania. Its colonisation success is a result of its rather small genetic diversity (parthenogenesis) and vast fluctuation variation which is manifest, among other things, in its wide tolerance to environmental factors. It is especially interesting that the native populations and those outside the natural range differ in their role as fluke hosts. The list of digeneans whose partenites were found in the New Zealand population includes 20 species; most of them use migratory birds or fishes as their ultimate hosts which suggests a great dispersal potential. Despite this parasite-infected snails were very rare in the population of $P$. antipodarum outside New Zealand. P. antipodarum as the first intermediate host of digeneans were only recorded in France and Poland. Digenean metacercariae are more frequent in the snails from outside the natural range, which results from the small host specificity of echinocer- 
cariae. Many authors explain the absence of parasite invasions in the populations of $P$. antipodarum from outside New Zealand by a high host-specificity of the digenean miracidia, manifest as (i) impossibility to penetrate the snail's integument, or (ii) quick elimination of penetrating larvae due to hormonal and cellular response of the host. The small compatibility may also cause (iii) high mortality of effectively infected snails in the colonised areas. Experimental infection of $P$. antipodarum from such populations con- firmed the impossibility of partenite development and the easy acquisition of metacercariae of various echinostome species. Population studies on the correlation between parasite invasion and pressure on sexual reproduction in the native areas provide positive verification of the hypothesis. In this context it is interesting to study the genetic diversity of populations colonising new areas, where parthenogenesis is closely associated with low parasite invasion. 